AWEJ for Translation \& Literary Studies, Volume 5, Number 2. May 2021

DOI: http://dx.doi.org/10.24093/awejtls/vol5no2.9

Pp. 115- 125

\title{
Insanity or Inspiration: A Study of Greek and Arab Thoughts on Poetry
}

\author{
Burhan Bashir \\ Department of Languages and Translation \\ College of Science and Arts at Al-Ula, Madinah \\ Taibah University, Kingdom of Saudi Arabia \\ Email: bwani@taibahu.edu.sa
}

Received: 3/5/2021

Accepted: 4/27/2021

Published: 5/24/2021

\begin{abstract}
The nexus between poetry, insanity, and inspiration is peculiar and can be traced back to earlier centuries. There are many examples in Greek and Arab literature where poetry is believed to have connections with divinity, possession, or even madness. The paper will try to show what Greeks and Arabs thought about the origin and the creation of poetry. It will attempt to show how early mythology and legends of both assign a supernatural or abnormal source to poetry. References from these two cultures will show the similarity in some theories like that of muses and supernatural beings, helping the poet achieve his goal. In order to show the similarity, many Greek and Arab philosophers/poets shall be referred to in the discussion. The methodology used shall be descriptive and analytical in nature.

Keywords: Arab, Greek, inspiration, insanity, madness, poetry

Cite as: Bashir, B. (2021). Insanity or Inspiration: A Study of Greek and Arab Thoughts on Poetry. Arab World English Journal for Translation \& Literary Studies 5 (2) 115- 125.

DOI: http://dx.doi.org/10.24093/awejtls/vol5no2.9
\end{abstract}




\section{Introduction}

The significance of sources in the creation of poetry is an age-old issue that has been discussed by many religious and literary scholars. Numerous studies try to show the connection between madness, inspiration, and poetry. This distinctive genre of literature is said to be the oldest form of writing of the Greeks and the Arabs. They seem to have answered some of the questions regarding the origin of poetry. Here, the research issue is not to arrive at a definite answer concerning the sources of poetry but to show a similarity of thought that runs through Greeks and Arabs. The reason to conduct such a study is to familiarize the English-speaking audience with ideas regarding the topic. Any discourse on poetry would be incomplete without paying attention to the aspects of the sources. The interpretations and the meanings of poems may differ significantly depending on our subscription to a certain theory. The significance of the study is apparent from the dearth of material in English on the said issue. It aims to provide an introduction to research issues in the field that may lead to other findings.

The study aims to answer the following questions:

1. How do Greeks and Arabs theorize the art of poetry with special reference to its sources?

2. How are religion and mythology pertinent in discussing the art of poetry?

3. In the case of poetry, is there any similarity in the theories put forth by Greeks and Arabs?

4. What is the role of insanity?

5. How is the concept of inspiration relevant to poetry?

The objectives of the research are as follows:

1. Provide an overview of the theories concerning poetry.

2. Identify key issues that are similar in Arabs and Greeks with reference to literature.

3. Present an analysis of the views held by two distinct cultures.

4. Study select religious and mythological texts.

\section{Literature Review}

While going through the works that have been written on or around the current study, the researcher found little or no material, especially in English, that deals with the similarity Greeks have with Arabs concerning poetry. Vílchez (2017) evaluates the discussions about arts and beauty in Arab culture from the pre-Islamic period till the fourteenth century. It devotes large sections to the numerous philosophers, religious scholars, and historians that contributed to the vibrant culture of Arabs in the past. However, it discusses the art of poetry vis-à-vis its sources in a passing reference only. It talks about Arab and Islamic aesthetics in general contexts. Although it introduces the English-speaking scholars to the Eastern theories, no serious attempt is made to draw parallels to Greeks when it comes to the art of poetry.

Al-Qurashī (1967) presents an anthology of Arab poetry from several authors dating eighth, ninth, and tenth centuries. The book is written in Arabic, and the English translation is not available to date. A good number of pages in the introduction discuss the art of poetry. It describes various encounters between the anthologized poets and the supernatural. The poet's consciousness is shown to be connected to that of divine inspiration. Dols (1992) deals with the issue of madness 
within Arab history. He uses a variety of sources including art, literature, and history to show the opinions of Islamic society on madness and the attitude of people towards those who suffered from it. The book also shows links between Muslim and Christian beliefs around the "fool" in its various forms. Again, the book does not provide a full-fledged account of poetry and its relation to madness. The book is immensely ambitious in its scope. It begins with the notions of madness found in the medieval Arab culture and then discusses kinds of treatments, physiological and psychological, such as cauterization and exorcism. The author writes on the three kinds of fools: the romantic fool, the wise fool, and the holy fool. El-Azma (1980), in his article, delineates the issue of poetry with reference to Quran and its various interpretations. His study shows the difference between the good poets and the bad poets as far as the Islamic ruling on them is concerned.

In his article, Boysen (2018) studies Plato's views on philosophy, madness, and poetry. He tries to establish a link between all three. He not only presents different views of Plato through his various dialogues but shows that poetry is a "twin brother to philosophy" and is very much related to madness as well. Farnell (2010) discusses cults of Greek culture focussing on many poets in particular. He presents a discourse on Greek mythology and its influence on many arts. Volume four of this book is especially important for the details regarding muses and the Greek god Apollo in connection with poetry. Plato (2002) examines the role of myths in ancient Greece. Rightly called a metaphilosophic dialogue, the book is essential in that it offers Plato's concepts of philosophy and poetry in a much more accessible way. A good portion of the dialogue is devoted to discussing poetry and its effect on others.

\section{Discussion}

Socrates seems to be the first philosopher ${ }^{1}$ who drew attention to the association of madness with poetry while offering a theory of the latter. He did not create the idea of madness in poetry, but he theorized the various implications of this union. His thoughts on poetic madness became the basis for others. There are speeches in Phaedrus and Ion that show what Socrates had to say regarding poetry and madness. He believed that "madness is fine, when it comes from divine dispensation" (Plato, 2002, p. 26). He mentions three types of madness that are very much acceptable and can be seen in prophets, religious rites, and poetry where the Muses inspire the poet. He says:

[T]he prophetess at Delphi and the priestesses at Dodona have done Greece a lot of good...in their madness, but little or nothing when they are in their right minds...

[I]t comes up with purificatory rituals, it makes the madman better, not just temporarily, but for the future too.

A third kind of possession and madness comes from the Muses. It takes hold of a delicate, virgin soul and stirs it into a frenzy for composing lyric and other kinds of poetry. (pp. 2627) 
Madness, according to Plato, is something that cannot be controlled, and this is the point that Socrates discusses at length in Phaedrus. If we consider this philosophy, then we may say that the creation of poetry is uncontrollable as well. The very beginning of Homer's (1945) Odyssey: "Tell me, O Muse, of the man of many devices" (p. 3) reveals the author's function in the production of poetry. He invokes an entity that shall inspire him to write/imitate the subject at hand. It means that poetry must take place somewhere else in the beginning; only then it can be transferred. The earliest critiques on literature by Socrates and Plato project an author merely as a medium via whom poetry becomes available to all. According to this Platonic theory ${ }^{2}$, the poet under the divine "inspiration" or "possession" is merely an agent to deliver the message from other entities. In the dialogues like Phaedrus and Ion, Plato shows that a poet does not add anything new to the message he has to deliver.

Cicero (2006) had a similar attitude concerning the theory of inspiration. He refers to Plato and Democritus in his argument as a source for this view. He remarks:

This exaltation shows that a divine power exists in the soul. For Democritus says that no poet can be great without frenzy, and Plato says the same. Let him call it frenzy, if he wishes, provided that the frenzy is praised as it was in Plato's Phaedrus. (p. 72)

The Muses and Apollo (as a Greek god of poetry) are a part of the mythology that reveals various attitudes of Greeks regarding poetry. They believed that the source of poetry is the gods themselves. Apollo "share[d] with the Muses the power of inspiring the poet, "the divine man"” (Farnell, 2010, p. 243). Pythia, the Oracle at Delphi, enjoyed this inspiration from them and produced her prophecies in poetic form. Fontenrose (1978) believes that facts don't support the theory of vapors or chasm. It was the inspiration rather than the effect of gases or chasm that led Pythia to her poetic expressions. Furthermore, he clarifies the confusion that surrounds the word mania as used by Greeks. He explains:

[T] he conception of the Pythia's madness, found in a few late writers, has its origin in Plato's conception of prophetic mania..., based on the word play mantikê/manikê and parallel to telestic, poetic, and amorous mania. And mania means transport, rapture, inspiration, ecstasy, not insanity, frenzy, delirium, hysteria...(p. 204)

The Platonic mania cannot be translated as madness or insanity since these words have pathological connotations attached to them. It is an emotional state of transport and inspiration.

Socrates has a conversation with a rhapsode named Ion. In the discussion, Socrates asserts that his performance works not by wisdom but by divine intervention, and that makes his rhapsody successful. He gives an analogy of prophets and seers who may say great things without their own design. He describes to him the chain that links Muse, poet, rhapsode, and listeners. The poet is a messenger/interpreter who is inspired by his Muse, the rhapsode is inspired and becomes a messenger of the messenger/poet, and finally, listeners are inspired by what they hear from the messenger of the messenger, i.e., rhapsode. In the following passage from Ion, Socrates believes that it is

Arab World English Journal for Translation \& Literary Studies 
a divine power which moves you like the stone which Euripides called Magnet, but most people call Heraclean. In fact, this stone not only attracts iron rings but also puts power in the rings so that they also have power to do the same thing the stone does and attract other rings ... So too the Muse herself causes men to be inspired, and through these inspired men a chain of others are possessed and suspended. For all our good epic poets speak all their beautiful poems, not through art, but because they're inspired and possessed, and so similarly our good lyric poets too. . . so lyric poets do not compose these beautiful songs in their right minds, but when they step to the mode and the rhythm they are filled with Bacchic frenzy ... (Plato, 1996, p. 14)

Ion is not exclusive in its scope when it comes to discussing the source of poetry. To comprehend this subject better, one needs to consult Phaedrus. Both Phaedrus and Ion support the notion of poetry where an author is marginalized to the extreme. The poetry, derived from divine madness or inspiration, will always be good as long as there is no personal intervention from an author. According to Ion,

[T] hey speak these things not by art but by divine power. . . A great proof of this is Tynnichus of Chalcis, who never produced another poem anyone would think worth remarking, but then produced the paean everyone keeps singing, very nearly the most beautiful of songs-completely, as he himself says, "a discovery of the Muses." In this especially, I think the god shows us in order that we may not doubt it that these beautiful poems are not human things nor of men, but divine things and of gods, and that poets are nothing other than messengers of the gods, each possessed by someone of the gods. (Plato, 1996, p. 14)

He mentions that Tynnichus is the worst poet of all, yet he could produce a song that all loved and sang. And all this was possible because some god wanted it to be so. If the worst poet can write a loveliest song, then it is not the poet but a god who is responsible for this poetic madness. This speaks well of Socrates' assumptions regarding the nature of poetry. It is important to note here as well that Socrates did not ban all poetry. He believes that a section of poetry is necessary under certain conditions. In Republic, he mentions:

Then we must first of all, it seems, supervise the storytellers. We'll select their stories whenever they are fine or beautiful and reject them when they aren't. And we'll persuade nurses and mothers to tell their children the ones we have selected, since they will shape their children's souls with stories much more than they shape their bodies by handling them. (Cooper, 1997, p. 1016)

One of the main concerns of Greeks related to poetry was the effect of poetry that it has on a writer as well as listeners. Many theories discuss this issue, but the one that is related to our study is that propounded by Socrates in the dialogue of Ion. He asks Ion a question about his state while he is reciting poetry to others. "[A]re you then in your right mind, or outside yourself?" asks Socrates. To this, Ion replies: "When I say something pitiable, my eyes brim with tears, and when I say something fearful or terrible, my hair stands straight on end from fear and my heart pounds" (Plato, 
1996, p. 15). These physical and emotional transitions clearly show the effect that poetry has on the reciter. Socrates tells Ion that he is not himself when he recites poetry because his actions and emotions are influenced by what he reads. Socrates asks another related question about the effect of poetry on listeners: "Do you know that you rhapsodes also affect the majority of your spectators the same way?" Ion replies in affirmative: "I know it very well. I look down from time to time from the stage and see them weeping and gazing up at me fearfully, sharing the astonishment of what is being said" (Plato, 1996, p. 15).

Talking about the effect of poetry in his Republic, Plato says that even philosophers like Socrates are not immune to its charm (Cooper, 1997). Poetry, according to him, has a quality of spell that bewitches all. Commenting on this, Boysen (2018) notes:

It seems obvious that the bewitchment of poetry is of an erotic nature. The erotic aspect of the bewitchment of poetry is accentuated by the description of it as a beloved ( $\left.\varphi^{i} \lambda \eta\right)$ or

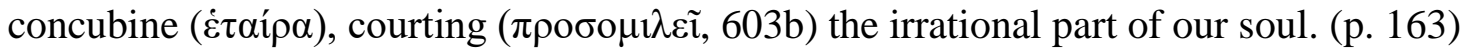

Plato's Republic is famous for its discussion on poets and their place in his city-state. Plato, in one place, mentions that there are certain ways of recognizing bad poetry. First, if a poem creates a bad impression on the audience by talking ill of gods or their works. Second, if the falsehood (which was believed to be one of the features of poetry) is not told well (Cooper, 1997). It is worth mentioning here that Plato holds a poet responsible for bad poetry because, according to him, a poet is incompetent and commits mistakes while interpreting the inspired message from gods. In fact, the gods don't lie, and they do not wish to mislead us. "A god, then, is simple and true in word and deed. He doesn't change himself or deceive others by images, words, or signs, whether in vision or in dreams" (Cooper, 1997, p. 1021). A poet is not able to produce the exact words of the Muses. He has to translate divine language into the human language, which is impossible, and this results in a gap. Therefore, a poet is an inferior being who falls short of repeating the divine language. The mistakes and the inconsistencies stem from the poet's art, not from the gods. The gods are not responsible for the lies created by poets. In Laws, Athenian illustrates the following to Clinias:

When a poet takes his seat on the tripod of the Muse, he cannot control his thoughts. He's like a fountain where the water is allowed to gush forth unchecked. His art is the art of representation, and when he represents men with contrasting characters, he is often obliged to contradict himself. (Cooper, 1997, p. 1405)

Plato's remarks on poetry in the Republic have a tone that is different from Ion and Phaedrus. He seems to conclude that poetry is just an illusion and deceit. A poet who writes under the effect of inspiration is not able to interpret the message from gods, just as he fails to imitate all other objects. The theory that shows a poet is possessed proves his incompetence simultaneously, whereas the imitation theory also shows the ignorance on the part of the poet.

The similarity of attitude between Arabs and Greeks regarding poetry becomes very obvious at certain points. The subject can be approached in two different ways of thought: (1) the 
pre-Islamic, (2) the one after the rise of Islam. The Qur' an mentions poets at various places, and in fact, one of the chapters is titled "The Poets." In the same chapter, the poet is said to have eccentric behavior. "As for the poets, the erring one's follow them. See you not that they speak about every subject (praising people - right or wrong) in their poetry? And that they say what they do not do" (Qur' an 26: 224-226). Arab literature has always categorized poets as madmen, mystics, and lovers. When Prophet Muhammad (peace be upon him) started calling people towards Islam, many of the enemies denied this call tagging him as a madman and a poet. They would say: "Are we going to abandon our âliha (gods) for the sake of a mad poet?" (Qur'an 37:36) There are many other verses ${ }^{3}$ in the Qur' an that deal with the similar claims made by these people against the Prophet Muhammad and other prophets before him. The Qur' an refutes all their claims saying that the prophets are neither poets nor madmen. "And we have not taught him (Muhammad peace be upon him) poetry, nor is it suitable for him" (Qur' an 36:69). Regarding the text of Qur' an, a verse in the chapter, "The Inevitable," states that it is not poetry. "It is not the word of a poet, little is that you believe." (Qur'an 69:41).

It is essential to know that Prophet Muhammad (peace be upon him) did not bar poetry altogether. What makes a poem permissible, even applaudable, is its content. If it is written to defend the teachings of the religion and counter the poetry of enemies, it is categorized as good. When the above-quoted verses of the chapter "The Poets" were revealed upon the Prophet, some of the Ansaari ${ }^{4}$ companions - Abdullah Ibn Rawahah, Ka'b Ibn Malik, Hassân Ibn Thâbit - came to Prophet crying that Allâh has revealed these verses and He knows that we are poets. (Al-Tabari, 2001). To this, the Prophet said that there is an exception for righteous poets by reciting the following verse from the same chapter:

Except those who believe (in the Oneness of Allâh - Islamic Monotheism) and do righteous deeds, and remember Allâh much, and vindicate themselves after they have been wronged [by replying in poetry to the unjust poetry (which the pagan poets utter against the Muslims)]. (Qur'an 26: 227)

There are some Hadith mentioned by Bukhari in his book where Prophet not only gave permission to Hassân Ibn Thâbit but invoked Allâh to help him through Gabriel: "O Allâh! Help him with the Ruh-ul-Qudus [Gabriel]." Gabriel, according to this tradition, was the one who was going to inspire the poet to produce good poetry. One Hadith related to this is narrated by Al-Bara': The Prophet said to Hassân, (the poet) "lampoon them (i.e., the pagans) and Jibrael (Gabriel) is with you" (AlBukhari, 1994, p. 182).

According to many scholars of interpretation of Qur'an, these verses concern two kinds of poets. One referred to above as companions, and second, the poets who were the enemies. Most prominent among the latter are

Abdullah Ibn Alzib'ara, Hubairah Ibn Abi Wahab Almakhzumi, Musaafie Ibn Abd Manaaf, Abu Uzza Jumha, and Ummayah Ibn Abi Alsalt. . . they claimed that they could say what Muhammad said, and people would come to listen to their poetry against the Prophet. (Khān, 1992, p. 428) 
These poets were famous for writing satires, especially against their enemies. The poets enjoyed a high status in Arab society before Islam. People believed them to be knowledgeable in almost all affairs of life. One of the connotations of the word shâ 'ir (poet) in Arabic tells us that he is "a man of extraordinary knowledge ... who knows things hid from common men and who possesses the council of unseen powers and uses the supernatural effects of satire to destroy his enemy" (ElAzma, 1980, p. 69). This definition of a poet in Arabic seems to be in complete harmony with many other sources. On several occasions, Prophet Muhammad (peace be upon him) expressed his views regarding the demons that accompany and inspire poets. One of them is mentioned by Muslim as: "We were met by a poet who was reciting poetry. The Messenger of Allah said: 'catch the devil' - or: 'restrain the devil'" (Muslim, 2007, p. 115)

To Arabs, poetry was a kind of sorcery using language. At the same time, a poet was believed to be a genius who can communicate with supernatural beings like genii ${ }^{5}$ who give him information that is not accessible otherwise. The language used by poets is likely to be obscure, as is the case of Delphic oracles. Arabs shared the concept of muses with Greek mythology. Like Greeks, they believed that each poet has a special kind of Rabbatu al-Sh'ir/Djinniyatu al-Sh'ir Shaytän al-Sh'ir (God of poetry/genie of poetry/demon of poetry) who inspires the poet and helps him making the magical verses.

On the authority of various narrators, Al-Qurashī (1967) quotes a number of people having conversations with genii. In these dialogues, the genii make it clear that it is they who "speak through the mouths of Arab poets." They claim that they are behind the beautiful poetry produced by famous Arab poets like Imru' Al-Qais, Al-Nâbigha, and Abeed Bin Al-Abras. An encounter with a genie named Mis'hal Ibn Jandal reads:

I asked him [the genie]: Who are the famous Arab poets? He said: Lâfiz bin Lâhiz, Hunât, Habeed, Hâdir Bin Mâhir. I said: I am not aware of these names. He replied: Obviously! As far as Lâfiz is concerned, he is the source of Imru' Al-Qais; Habeed is the source of Abeed Bin Al-Abras and Bashr; Hâdir is the source of Al-Nâbigha Al-Zabiyani and AlNâbigha. (pp. 49-50)

Interpreting the chapter "The Poets," Zamakhshari and Al-Tabari suggest that the word ghâwun carries the meaning of Shayäteen (genii) in addition to other meanings given by others. According to this interpretation, the poets are followed by genii. Furthermore, this interpretation leads to some other possibilities as mentioned by El-Azma:

(a) Either the verse refers to the belief of the Jâhiliyah that the poets are inspired by supernatural beings (or the demons), (b) Or the verse is a reversive statement, a rhetorical way not alien to the Qur'anic style. Making the demons follow the poets is an emphatic form of speech to renounce the poets' obedience to them. (p. 75)

Some of the prominent interpreters explain the word wâdi in verse 26 of the chapter "The Poets" literally as the valley of genii. There were several places that people considered to be abodes of genii, and the valley of Abqar is one of them. It would mean then that these poets would wander in the valleys like these to receive the help/inspiration from the genii. "It is more likely that the 
poets are those who follow the demons, and the follow them in their own abodes, the wâdis" (ElAzma, 1980, p. 75). This is to say that poets were not wholly responsible for their poetry. They took help from beings "whom they called a demon (shayțann), to whom they attributed the senses possessed by human beings: sight, touch, hearing...They imagined them as prodigious occult "forces" that lay behind natural phenomena..." (Vilchez, 2017, p. 32). The Shaytān responsible for poetry in Arab, like the Muse, connects a particular poet to the supernatural world of creation, bestows upon him a unique character that makes him superior among others. This shaytān of poetry is the one who transforms an ordinary human language into a special one.

\section{Conclusion}

There are many instances where Arab poets are found expressing their connection with muses or Shayțān al-Sh 'ir. For example, Imru' Al-Qais says: "I am the gifted one, around me are the genii that tell me what to say" And Jarir says: "The poetry is recited over me by shayāteen." (as cited in Al-Saihī, 2017). Dols (1992) also mentions this nexus between poetry, inspiration, and madness. He writes:

The early Arab poet Farazdak had a companion named Hamim (or Hamam), and the poet al-A'sha had Mus'hil. And the majnun could be possessed by heavenly spirits. The notion that a madman could be the recipient of supernatural wisdom was ancient. (p. 216)

Connecting the art of poetry with madness is yet another area where Arabs are seen to have a somewhat similar reaction as Greeks. A sane man cannot come up with verses that have a special effect. It is either under the influence of a supernatural entity or a state of mind that is not normal for the general public. For Dols (1992), the term majnun has more than one connotation: "[T]he term majnun, 'the possessed,' was quite ambiguous, ... and it evoked ambivalent feelings. Majnun might mean any of these 'altered states' of consciousness, depending on his outward appearance, his actions, and his utterances" (p. 216)

This study shows that Greeks have a long history of theorizing the art of poetry. The various ideas and contentions are found in their early mythology. Prominent philosophers like Plato, Socrates, and many others have contributed to this field. While some are of the opinion that poetry is nothing but madness, others argue that poetry comes from the gods. Muses, according to the many Greek sources, help the poets in producing poetry that influences the readers and listeners. Their belief in the effect of poetry was so strong that it led many to bar the poetry altogether. Their discussions on poetry, as referred to above, reveals that religion and the belief in other supernatural beings dominated their thinking. This study makes it clear that the Arabs in this regard are not very different from the Greeks. The people from the pre-Islamic era believed that poetry is not possible without the help of the supernatural. According to Arabs, a poet is just a common man with regular capabilities. What makes him superior is his connection with genii. The poet enjoyed a high status in the Arab culture because of his contact with the supernatural. It is equally interesting to see how scholars in the Islamic era confirm the prevalent ideas in this respect. While many Arabs take poetry as a form of madness, many others believe that the form and the content do not belong to the poet, but to the entity that is beyond our regular comprehension. The effect of the poetry on listeners and its relation to religion is very much apparent from the above-quoted sources. 
Plato could bar poetry only in his imagined city-state, not in real life. It continued to be an essential part of their lives. There is a similar pattern to been seen in Arabs regarding poetry. If the opponents ban poetry on religious grounds, the proponents relish it for the same reasons. It is a well-known fact that most of the commentators of the Qur'an or Hadith use poetry in their explanations. It continues to be an essential thread that holds together the fabric of the Arabic language. The literary tradition of poetry in Arabs and Greeks that exists to this day in hundreds of volumes proves that the appreciation for this art remains intact in these cultures.

\section{Endnotes}

${ }^{1}$ Plato offered us two versions of Socrates. Scholars generally believe that Socrates of the early dialogues like Ion, Hippias Major, Hippias Minor, Laches, and Protagoras presented Socrates's own philosophy. Plato continued to use Socrates as the main character throughout middle and later dialogues. In these, he used Socrates as a mouthpiece for his own philosophy.

${ }^{2}$ The other theory is that of mimesis, where Plato believes that a poet is just an imitator who creates a superficial version of a thing. However, in both cases, he avers that the poet's end product is futile as it is not based on accurate knowledge.

${ }^{3}$ For details, see these chapters and verses from the Qur'an (the translation of chapters is taken from Hilali and Khān): The Rocky Tract 15:6, The Prophets 21:5, The Poets 26:27, The Smoke 44:14, The Winds that Scatter 51:39 and 52, The Mount 52: 29, The Moon 54:9, The Pen 68:2 and 51, Wound Round and Lost its Light 81:22.

${ }^{4}$ These are the companions who were from Madinah. It is debatable among scholars whether the whole or a part of this chapter is Makki (chapters revealed before Hijrah) or Madani (chapters revealed after Hijrah). Ibn Kathīr raises this issue, saying that how come that these verses were revealed in the case of Ansari poets? (Ibn-Kathīr, 2000, p. 387) Many believe that this chapter is Makki except for the last verses.

5 The word used in Hadīth is 'Shaytānn,' which has been translated differently by various authors. The related words used for this term are demon, devil, djinn, genie (plural genii). Shaytān, according to Qur' an, was from djinns who went rogue. The word 'genii' used in the paper represents a force that influences the human and intervenes in the creation of poetry.

\section{About the author}

Burhan Bashir is an Assistant professor at Taibah University in the Department of Languages and Translation at Al-Ula, Madinah. He completed his PhD at Aligarh Muslim University and his MPhil at Jamia Millia Islamia. His research interests lie in the area of resistance literature, contemporary poetry, literary theory, and translation. He has translated poems and short stories from Arabic/Urdu into English. He has also published research papers in various online and print journals.

ORCID ID: https://orcid.org/0000-0001-7735-0832

\section{References}

Al-Bukhari, M. I. (1994). Sahih Al-Bukhari [The Collection of Prophet's Authentic Sayings by Bukhari]. (M. M. Khān, Trans.). Riyadh: Maktaba Dar-us-Salam.

Al-Qurashī, A. Z. (1967). Jamharat Ash'ar al-Arab fi al-Jaahiliyah wa al-Islam [A Collection of Arab Poetry Before and After the Rise of Islam]. Egypt: Matba'ah Nahzah Misr.

Al-Saihī, R. (2017). Al-Shaytan fi Al-Ibdaa' Al-shi'ri [Role of Satan in Poetic Expressions] El Sada. Available at http://elsada.net/41554/

Al-Tabari, I. J. (2001). Jami al Bayan an Ta'weel Aay Al Quran [A Comprehensive Interpretation of the Verses of the Quran], vol. 17. Cairo: Dar al Hijr. 
Boysen, B. (2018). Poetry, Philosophy, and Madness in Plato, Cogitans, 13(1), 154-184.

Available at https://tidsskrift.dk/res_cogitans/article/view/104634

Cicero. (2006). Cicero on Divination: De Devinatione (D. Wardle, Trans.). Oxford: Clarendon Press.

Cooper, J. M. (Ed.). (1997). Plato: Complete Works. Cambridge: Hackett Publishing company.

Dols, M. W. (1992). Majnun: The Madman in Medieval Islamic Society. New York: Oxford University Press.

El-Azma, N. (1980). The Qur'an and Poetry. Al-' Arabiyyah, 13(1/2), 65-79. Retrieved from https://www.jstor.org/stable/43192525

Farnell, L. R. (2010). The Cults of the Greek States, vol. 4. New York: Cambridge University Press.

Fontenrose, J. (1978). The Delphic Oracle. California: University of California Press.

Homer. (1945). The Odyssey (A. T. Murray, Trans.). Cambridge: Harvard University Press.

Ibn-Kathīr, E. A. D. (2000). Tafseer Al-Quran Al-Azeem [The Interpretation of Glorious Quran], vol. 10. Cairo: Mu'assah Qurtubah.

Khān, S. H. (1992). Fath al-Bayan Fee Maqasid al Quran [The Revelation of the meanings of Quran], vol. 9. Beirut: Maktaba Al Asariyyah.

Khān, M. M., \& Hilālī, T. A. D. (1984). Interpretation of the Meanings of the Noble Qur'an in the English Language. Madinah: King Fahd Holy Qur'an Printing Complex.

Muslim, A. H. (2007). Sahih Muslim [The Collection of Prophet's Authentic Sayings by Muslim], vol. 6 (N. al-Khattab, Trans.). Riyadh: Maktaba Dar-us-Salam.

Plato. (1996). The Dialogues of Plato: Ion, Hippias Minor, Laches, and Protagoras, Vol. 3 (R. E. Allen, Trans.). New Haven: Yale University Press.

Plato. (2002). Phaedrus (R. Waterfield, Trans.). New York: Oxford University Press.

Vilchez, J. M. P. (2017). Aesthetics in Arabic Thought: From Pre-Islamic Arabia through alAndalus (C. L. Morillas, Trans.). Leiden: Brill. 